\title{
Conservation of India's agrobiodiversity towards increasing food, nutritional and livelihood security
}

\author{
C. Thomson Jacob*, Ajay Parida and N. K. Krishna Kumar
}

India is rich in agrobiodiversity and considered to be one of the centres of origin of food crops, oilseed crops, horticultural crops, spices and medicinal plants. Biodiversity and agriculture are strongly interrelated, and the country has around 811 cultivated plants and 186 breeds of livestock and poultry. Some of the challenges India is facing in terms of loss of agrobiodiversity include: chemical-intensified agricultural farming and increasing replacement of locally adopted and traditionally grown cultivars by high-yielding modern varieties, soil degradation, fragmentation, excessive tillage, inappropriate crop rotation, water scarcity, post-harvest losses, natural disasters and climate change impacts. The objective of the present study is to increase agrobiodiversity of India by conserving the landraces, wild varieties, folk varieties, cultivars, domesticated stocks and breeds. To undertake this study, a policy analysis of various schemes, missions and programmes of the Ministry of Agriculture and Farmers' Welfare, Government of India was carried out and recommendations were put forth towards promoting ecologically intensified agricultural farming practices by integrating ecological principles.

Keywords: Agrobiodiversity, conservation, genetic resources, nutritional and livelihood security.

\section{India's agrobiodiversity wealth}

AGRICULTURE and allied sectors provide food and nutritional security for about 1.3 billion Indians. Nearly $54.6 \%$ of the population is engaged in agriculture and related activities, and this contributed $17.4 \%$ to the country's gross value added during 2016-17 (ref. 1). India is the centre of origin of rice, brinjal, citrus, banana and cucumber species, and it is rich in food crops, oilseed crops, horticultural crops, spices, lichens, algae, fungi, insects and medicinal plants. The country has around 15,658 rice landraces, is the largest exporter of Basmati rice and produces several indigenous and local varieties of wheat, pulses and millets that have high nutritional value. Some of the promising genetic resources of India include landraces of rice from Tamil Nadu (Konamani), Assam (Agni bora), and Kerala (Pokkali); Bhalia wheat and Bannigrass for cattle feed from Gujarat; wild mushroom (Gucchi) from Himachal Pradesh, and buffalo (Murrah and Jafarabadi) from Haryana and Gujarat ${ }^{2}$. The country is also

\footnotetext{
C. Thomson Jacob formerly with the Centre for Biodiversity Policy and Law, National Biodiversity Authority, Chennai 600 113, India; Ajay Parida is in the Institute of Life Sciences, Bhubaneswar 751023 , India; N. K. Krishna Kumar formerly with the Bioversity International, New Delhi 110 012, India.

*For correspondence. (e-mail: tomson09@yahoo.co.in)
}

the largest producer of spices, which includes ginger, turmeric, cardamom, clove, cinnamon, black pepper, mace, mustard, nutmeg, fennel, asafoetida, etc. India has a rich livestock and poultry breeds that provide a range of products such as milk, meat, egg, fibre, fuel, etc. For conserving the unique agrobiodiversity, India is adhering to various global and national governance mechanisms.

\section{Global and national governance}

The Convention on Biological Diversity (CBD) provides a global framework for conservation and sustainable use of biodiversity. The Food and Agriculture Organization's (FAO) commission on Genetic Resources for Food and Agriculture is an intergovernmental permanent forum to discuss and negotiate matters relevant to agricultural biodiversity. The International Treaty on Plant Genetic Resources (PGRs) of FAO facilitates conservation and sustainable use of all PGRs, and fair and equitable sharing of the benefits. The Nagoya Protocol is a legally binding framework to promote transparent and effective implementation of the access and benefit-sharing concept at the regional, national and local level. Some of the national frameworks in India dealing with agriculture and the food sector include: National Agricultural Policy, 2000; National Policy for Farmers, 2007; National Seed Policy, 
2002; National Policy on Agroforestry, 2014; National Policy on Biofuels 2009; Insecticides Act, 1968; Livestock Importation Act, 2001; Protection of Plant Varieties and Farmers' Rights Act (PPV\&FRA), 2001 and Biological Diversity (BD) Act, 2002.

\section{Aichi, national targets and Sustainable Development Goals}

Food production and agriculture have significant implications for all of the Aichi biodiversity targets and in particular the target 3 (incentives reforms), target 4 (sustainable consumption and production), target 7 (sustainable agriculture), target 9 (invasive alien species prevented and controlled), target 13 (genetic diversity maintained) and target 16 (Nagoya Protocol in force and operational). Some of India's national targets that address agricultural issues are target 5 (sustainable management of agriculture) and target 7 (genetic diversity maintained and minimizing genetic erosion) $)^{3}$. The Sustainable Development Goals (SDGs) relevant to the agricultural sector include SDG 2 (end hunger, achieve food security, improve nutrition and sustainable agriculture); SDG 12 (ensure sustainable consumption and production patterns) and SDG 15 (halt biodiversity loss) ${ }^{4}$.

\section{Concerns}

India's agriculture is focusing on increasing production through the development of new varieties, breeds, technologies and practices. The quest for increased production and productivity has resulted in overexploitation of natural resources, and nearly $37 \%$ of the geographical area in the country is affected by different kinds of land degradation ${ }^{5}$.

\section{Increased usage of agricultural chemicals and fertilizers}

The excessive usage of chemical fertilizers (370.03 lakh metric tonnes (LMT) during 2014-15) which erode land quality, pollute groundwater and surface water bodies, and the subsidy on phosphorus and potash (P\&K) fertilizers have increased from Rs $19,389.64$ crores (2005-06) to the Rs 77,268.56 crores during 2014-15 (ref. 6). The use of nitrogen, phosphorus and potassium (N, P205, K 20) has increased from 1.1 million tonnes $(\mathrm{mt})$ in 1966-67 to more than $25 \mathrm{mt}$ in 2014-15 (ref. 7). India ranks second in total world fertilizer and the average consumption of fertilizer has increased from $69.84 \mathrm{~kg} / \mathrm{ha}$ in $1991-92$ to $128.08 \mathrm{~kg} / \mathrm{ha}$ in $2014-15$ (ref. 8).

\section{Fragmentation}

About $85 \%$ of the operational holdings in the country are small and marginal, i.e. holding less than 2 ha each.
Increasing fragmentation of landholding is a continuous cause for concern, and the number of landholdings has increased from 75.41 million to 92.83 million during 2001-11. These small landholders put stress on ecosystems, for example, through modification of landscape, over-extraction of water and nutrients, and use of pesticides. This increases the stress on ecosystem functioning ${ }^{9}$.

\section{Soil degradation}

Out of India's total geographical area of $328.7 \mathrm{~m}$ ha, about $120.4 \mathrm{~m}$ ha is affected by various kinds of land degradation, which includes water and wind erosion (94.9 m ha), waterlogging (0.9 m ha), soil alkalinity/ sodicity (3.7 m ha), soil acidity (17.9 $\mathrm{m} \mathrm{ha})$, soil salinity $(2.7 \mathrm{~m} \mathrm{ha})$ and mining and industrial waste $(0.3 \mathrm{~m} \mathrm{ha})^{10}$.

\section{Excessive tillage and inappropriate crop rotation}

Excessive tillage coupled with heavy machinery reduces organic matter, microbes, earthworms, ants and fungal hyphae. Also, inappropriate crop rotation together with lack of proper soil and water conservation measures are seen as significant drivers of soil erosion. The rotation of crops provides varied diet to soil microorganisms and promotes diverse soil flora and fauna ${ }^{11}$.

\section{Loss of agrobiodiversity}

The loss of agricultural biodiversity leads to the decline of many ecosystem services and threatens the productivity and sustainability of agriculture. It also reduces distribution and abundance of populations of species, loss of genetic diversity and unique habitats. The increasing demand for food combined with socio-economic developmental efforts threaten the existence of traditional varieties and lead to the destruction of natural habitats of wild species. This has resulted in narrowing of the genetic base - 'genetic erosion' and 'genetic wipeout' 12 .

\section{Approaches and best practices for mainstreaming biodiversity}

The Subsidiary Body on Scientific, Technical and Technological Advice of the CBD has suggested countries to adopt: (a) ecological intensification of production; (b) maintenance of biodiversity in the production landscapes and (c) sustainable consumption, reduced food waste and sustainable diets towards addressing biodiversity concerns into the agriculture sector ${ }^{13}$. Some of the best practices for mainstreaming biodiversity into the agriculture sector are: promoting native biodiversity, increasing the production and consumption of unrefined, nutrient-rich 
foods (fruits, vegetables, beans, nuts and seeds), nutrition-sensitive landscape approaches, control of phosphorus pollution, positive incentive measures (abolishment of distorting subsidies), maintaining the genetic diversity of resources for food and agriculture and their landraces and wild relatives, promoting voluntary/organic certification schemes for sustainably produced goods and services, promoting pollinators and improving soil biodiversity, documentation of traditional knowledge practised by the indigenous/local communities, reduction of post-harvest loss, encouraging traditional farming practices and eradication/control of invasive alien species ${ }^{14}$.

\section{Discussion and recommendations}

\section{Promoting ecologically intensified agricultural practices}

Ecological agriculture is a natural based farming practice, growing food in diverse systems that are $100 \%$ organic. They build and maintain soil fertility through maintaining the right mix of plant species and make more use of multifunctional trees and other perennial plants ${ }^{15}$. The objective of promoting ecological agriculture is to produce optimal crop yield and quality with high positive and low negative environmental effects. The ecological agricultural farming helps farmers to make use of nature's goods and services in an economically, environmentally and socially rewarding way, and this helps in conserving agrobiodiversity. Some of the agricultural practices which promote ecological agriculture farming systems include: organic agriculture, ecological pest management, use of organic pesticides and insecticides, crop rotation, recycling crop and animal waste, mixed farming, multicropping, etc. The organic agriculture practices increase species richness by an average of $30 \%$ (ref. 16) and also increase the abundance of biomass of all soil organisms. Sikkim is the first state in India which officially

Table 1. Crop wild relatives of India

\begin{tabular}{lccc}
\hline Crop-group & Crops & CWR species & Taxa \\
\hline Plantation crops & 03 & 12 & 14 \\
Vegetables & 25 & 76 & 87 \\
Fruits and nuts & 36 & 127 & 144 \\
Spices and condiments & 12 & 50 & 54 \\
Medicinal and aromatic plants & 20 & 70 & 81 \\
Pseudocereals & 03 & 13 & 13 \\
Cereals and millets & 13 & 72 & 83 \\
Grain legumes & 10 & 49 & 57 \\
Oilseeds & 04 & 09 & 10 \\
Fibres & 05 & 18 & 20 \\
Forages & 16 & 58 & 63 \\
Ornamental plants & 13 & 141 & 152 \\
Others & 08 & 35 & 39 \\
Total & 168 & 730 & 817 \\
\hline
\end{tabular}

Source: National Bureau of Plant Genetic Resources, 2018. announced the adoption of organic farming and converted around 75,000 ha of agricultural land area as organic ${ }^{17}$.

This study recommends a comprehensive, well-defined policy on 'ecological agriculture' for sustaining India's agrobiodiversity. Incentives need to be provided for: (a) cultivating native indigenous land-race varieties; (b) producing biofertilizers, micronutrients (e.g. production of bio-NPK, BioPhos, BioPhos+, BioZinc, BioPotash) and (c) producing organic pesticides. The Soil Health Card Scheme implemented by the MoA\&FW, GoI is a successful programme which analyses NPK content and also micronutrients (such as boron, copper, iron, manganese, sulphur and zinc) available in the agricultural field. It also helps in minimizing the usage of chemical fertilizers. A comparative research study needs to be carried out by assessing biodiversity richness (soil arthropods and microbes) in the organic and chemical-intensified agricultural farming areas.

\section{Conservation of agrobiodiversity}

Conservation of plant genetic resources: Globally around 300,000 species of higher plants have been documented. However, only about 7000 species have been domesticated and cultivated by humans over millennia for food, fodder and feed. Today, our nutrition is supplied by 30 plant species because they provide $95 \%$ of dietary energy or protein. The CBD defines PGRs as any living material of present and potential value for humans. PGRs include all our agricultural crops and some of their wild relatives because they possess valuable traits. India's national gene bank conserves around 0.4 million accessions belonging to about 1800 species. The National Bureau of Plant Genetic Resources (NBPGR) and other sister institutions are the custodian of these diverse germplasms and promotes their use in the breeding programme ${ }^{18}$. The Indian gene centre conserves several major cereals, millets, pulses, vegetables and fruits of international importance.

Crop wild relatives (CWRs): CWRs are crucial for maintaining genetic diversity and their loss has serious consequences on food and nutritional security. The NBPGR has shortlisted CWRs of 168 native crops belonging to 730 species, which include cereals, millets, oilseeds, fibres, forages, fruits and nuts, vegetables, spices, medicine and aromatic, etc ${ }^{19}$.

The traditional and wild relatives of crop plants are an increasingly important source of genetic variation. Hence it is necessary to map (state-wise) the on-farm conservation (crops) sites protected by local farmers and their cultivation practices. This is recommended to provide incentives for farmers involved in protecting traditional varieties of food crops. Landraces and traditional farmers' varieties should be conserved through ex situ and in situ on-farm conservation measures and by ensuring continuous availability of their quality seed materials. It 
is also suggested that all the traditional varieties available with the agricultural farmers and the private/public sector need to be registered with the national repositories. The agrobiodiversity hotspots (e.g. Western and Eastern Himalaya, Northeastern Hills, Koraput, Konkan region, Malabar region, etc.) must be protected and an Agro Biodiversity Index (ABI) must be prepared for these agrobiodiversity rich areas along with valuation of ecosystem services. The CWRs important for food and nutritional security need be mapped, characterized and conserved; cryopreservation of threatened plants and CWRs should be prioritized.

Conservation of livestock and poultry breeds: Among over 40 animal species domesticated by man, 14 major species contribute $82 \%$ of global food and agricultural production. There are 184 livestock and poultry breeds available in India, which include 43 cattle, 16 buffalo, 43 sheep, 34 goats, seven horses and pony, nine camels, eight pig, two donkeys, one yak, 19 chicken, one duck and one goose ${ }^{20}$. FAO warns that out of about 6400 livestock breeds around the world, one-third is endangered. Further, the need for conservation of animal genetic resources is essential for the preservation and maintenance of existing breeds ${ }^{21}$.

The study carried out under the Centre for Biodiversity Policy and Law Programme designate countrywide regions as 'hotspots' for animal genetic resources (AnGRs) as well as prepare a national/state-level watch list for the rare/threatened breeds, and necessary rehabilitative measures must be taken for such species. To formulate long-term breeding plans for genetic improvement vis-àvis conservation of indigenous breeds and strengthen the national gene bank through a two-tier system (e.g. one at the state level and these need to be networked with the other livestock farms at the national level); to declare livestock farms as in situ conservation centres in their native tracts. The indigenous knowledge of local and pastoral communities in utilizing the genetic diversity in their livestock need to be documented in People's Biodiversity Register. It is suggested to provide incentives for communities who conserve indigenous breeds and document the genetically pure livestock and associated traditional knowledge. These local breeders must be rewarded (e.g. similar to the Protection of Plant, Varieties and Farmers' Rights Authority award) and a legal mechanism for the exchange of AnGR and benefit-sharing modalities for livestock keepers and gaushalas must be developed.

\section{Conservation of pollinators}

Pollination is the introductory process leading to the production of offspring in flowering plants ${ }^{22}$. Pollinators are essential for the production of fibre crops, cereals, orchards, horticultural and forage crops. The diverse groups of pollinators in the animal kingdom include bees, birds, bats, opossums, giraffes, reptiles, flies, beetles, moths, butterflies and wasps. It was reported that nearly $90 \%$ of the world's wild flowering plant species depend, entirely or at least in part, on animal pollination. More than threequarters of the leading food crops benefit to some extent from animal pollination, with an estimated annual market value of US\$ 235-577 billion in 2015 (ref. 23). According to the Intergovernmental Science-Policy Platform on Biodiversity and Ecosystem Services (IPBES) ${ }^{24}$, nearly $5-8 \%$ of global crop production depends on animal pollination, and the diversity of pollinators decreases due to intensive agricultural practices. As two-thirds of the world's major food crops are pollinator-dependent, conversely the increase in wild insect pollinator richness and abundance was observed in high and more consistent crop yields. For achieving 50\% pollination threshold in a single site requires an average of 5.5 bee species, and for larger regions 55 species are required ${ }^{25}$. The decline in pollinator species will negatively affect agriculture productivity and sustainability.

To increase pollinators in the agricultural landscape, an insect hotel can be provided by planting native trees, herbs, climbers and flowering plants in the fences of agricultural fields. Necessary ecological infrastructure such as hedges, small ponds and beetle banks can also be created to provide habitats for native pollinators. Along with honey bees, other native agriculturally important insects, viz. moths, wasps, beetles, etc. and native bees such as Amegilla zonata and Hoplonomia westwoodi can be promoted under the Mission of Integrated Development of Horticulture, Government of India (GoI).

\section{Conservation of traditional seed varieties}

Globally, community seed banks (CSBs) have been initiated at the local level to conserve minor crops and neglected and underused species, and to provide superior quality seeds. Farmers have documented traditional knowledge associated with these genetic resources in various farms with valuable traits, such as tolerance to drought, flooding, diseases and insects; good eating qualities; market-preferred traits; long fruiting period; religious and cultural importance. In India, the local farmers use CSBs for exchanging genetic resources from the common gene pool ${ }^{26}$. Nearly $80 \%-90 \%$ of seeds used by smallholder farmers in developing countries are sourced from the informal seed system: saved from their own crops, bought from a market or shop, or exchanged with friends and neighbours. Community-level seedsaving initiatives include seed huts, seed libraries, seedsaver groups, and many others ${ }^{27}$. CSBs will help farmers conserve existing indigenous crop diversity in a region and maintain availability in the formal seed systems. With this the seed supply within a community can be 
streamlined and a huge diversity of seeds of various crops can be made available to the farmers. In India, NBPGR conserves the traditional varieties in gene banks located at different states.

The present recommends that CSBs be set up on a priority basis in each agro-climatic zone so that their regional biotic properties are saved, and this can be utilized by the new-generation farmers. While distributing seeds to the farmers, $5 \%$ of traditional seed varieties with $100 \%$ subsidy can be included through the National/State Seed Corporations. CSBs can be encouraged in the centres of traditional seed diversity areas that hold PGRs of food, fodder, nutrition, health and income value. While releasing high-yield varieties/seeds, other crop varieties also need to be considered providing importance to biodiversity. For storing seeds, the hermetic storage system (zeolite beads reduce the moisture content of seeds kept adjacent hermetically) is highly recommended, and this can be promoted.

\section{Policy and institutional strengthening}

The BD Act, 2002, defines agrobiodiversity as agriculture-related species and their wild relatives. It is important that the conservation and sustainable utilization of agriculturally important plants, animals and microbes need to be effectively integrated into the biodiversity strategies, plans and programmes of the MoA\&FW, GoI. Some of the issues that need immediate attention includes: (a) protection of landraces/traditional crop varieties; (b) policy on conventional breeding, and (c) conservation of wild relatives of crop plants, etc. For strengthening the implementation of BD Act into the agricultural sector, the following are recommended: (a) This concerned State Governments in consultation with the local biodiversity management committee should notify the agrobiodiversity hotspots as Biodiversity Heritage Sites (BHS). The PPV\&FRA has already identified 22 agrobiodiversity hotspots and these can be considered for BHSs. (b) For sustainable utilization of livestock and animal breeds, it is recommended to list out animals and animal products and notify them as 'Normally Traded as Commodities'. (c) Guidelines need to be prepared for utilizing the national, state and local biodiversity funds accrued as royalties, and modalities need to be evolved for sharing the benefits to the benefit claimers. (d) A singlewindow clearance system can be developed by integrating National Biodiversity Authority (NBA), PPV\&FRA, Patent Office, State Biodiversity Boards (SBB), Biodiversity Management Committees (BMCs), etc. to make the entire process simple and transparent. (e) There must be clarity regarding the use of foreign microbes by Indian companies. (f) National-level invasive alien microbes by Indian companies species strategy need to be developed for identifying the pathways, mapping, monitoring, managing, controlling and eradicating agriculture-related invasive alien species and a database of these species must be developed. Finally it is suggested to include biodiversity experts in the national/state and district level committees for implementing various missions of the MoA\&FW, GoI.

\section{Conclusion}

India is rich in agrobiodiversity and the conservation of plant and animal genetic resources plays a crucial role in providing food, nutritional and livelihood security for human well-being. For this, biodiversity provides genetic materials for crop cultivation, breeding and varietal improvement of traits. Agrobiodiversity holds important keys for the future adaptation of agriculture to climate change, disease-related risks and increased resilience. For doubling India's agricultural productivity, it is important to increase the agrobiodiversity wealth of the country. With the advent of modern agriculture, several locally adopted crop varieties were replaced by genetically uniform, high-yielding modern varieties. In India, that once grew 30,000 rice varieties, the number has now reduced significantly. Many local cultivars and landraces have been restricted to small areas, which is a matter of concern in terms of narrowing down of the genetic base. The loss of agrobiodiversity in our global food production systems is also an issue of increasing concern. When we lose agricultural biodiversity, we also lose the option to make our diets healthier and our food systems more resilient and sustainable.

Today, our nutrition is supplied by 30 plant species because they provide $95 \%$ of dietary energy or proteins. The diversification of agriculture with new species of major crops may enhance plant productivity, quality, nutritional value and reduce environmental stress caused by monoculture. Some species of potential importance are not yet fully utilized because of their limited competitiveness with major crops. Thus it is essential to map the traditional crop varieties of cereals, pulses, vegetables, fruits, forages, medicinal and aromatic plants having high nutritious value. Increased diversification of crop species will not only enhance food and nutritional security, but would provide farmers with several options to face the uncertain weather conditions associated with increased climate variability.

The production of underutilized crop varieties for food, nutrition and medicinal value needs to be increased, and marketing strategy developed for promoting these crops. The present study recommends increasing the agrobiodiversity wealth of India by providing incentives for conserving traditional crop varieties and breeds. This will help farmers conserve the localized plant and animal genetic resources of the country. The CWRs are a source of traits and genetic diversity for agriculture. Plant 
breeding has benefitted from CWRs to develop more nutritious varieties, as well as those tolerant to biotic and abiotic stresses. The CWRs of high significance need to be mapped and those available inside Protected Areas need to be explored on priority. Also, it is suggested that the traditional seed varieties conserved by the local communities need to be encouraged and storage mechanism of seeds must be improved by adopting hermetic storage system.

It is also noted that India's agriculture production is tilting towards chemical-intensified farming practices. It is strongly recommended to have a comprehensive policy on ecological agriculture for sustaining the country's agrobiodiversity. For maintenance of biodiversity in the production landscape, it is recommended to promote native, agriculturally important insects and bees in the agricultural landscapes by growing hedges, cooling ponds and flowering plants in the from fences to attract insects and bees. To strengthen the implementation of the BD Act, it is recommended to: (a) identify the agrobiodiversity important areas and notify them as BHS; (b) list out animals/animal products under the 'Normally Traded as Commodities' as similar to plants varieties; (c) create a single-window clearance for processing ABS applications and prepare guidelines for utilizing the biodiversity funds for benefit-sharing and (d) develop national policy/ strategy for controlling and managing the invasive species. By adhering to the above recommendations, it is assured that the agrobiodiversity wealth of India can be enhanced for food, nutritional, health and livelihood security of the country.

1. Annual Report of Agriculture 2017-18, Ministry of Agriculture and Farmers' Welfare (MoA\&FW), Government of India (GoI).

2. Paroda, R. S. et al. (eds), Proceedings of the First International Agrobiodiversity Congress: Science, Technology and Partnership, Indian Society of Plant Genetic Resources, New Delhi and Bioversity International, Rome, Italy, 2017, p. 152.

3. MoEFCC, National Biodiversity Action Plan (NBAP) Addendum 2014 to NBAP, Ministry of Environment, Forest and Climate Change, GoI, 2008.

4. UNDP, Linking sustainable development goals to national biodiversity targets. Biodiversity Finance Initiative, United Nations Development Programme, 2016.

5. MoA\&FW, Annual Report of Agriculture 2017-18, GoI.

6. Department of Chemicals and Petrochemicals, Annual Report 2015-16, Ministry of Chemicals and Fertilizers Department of Chemicals and Petrochemicals, GoI.

7. Ministry of Statistics and Programme Implementation, GoI; http://www.mospi.nic.in (accessed on December 2018).

8. MoEFCC, State of Environment Report, 2015 (Draft), Ministry of Environment Forest and Climate Change, GoI.

9. MoA\&FW, Fourth semi-annual medium term agricultural outlook report, September, 2015, National Council of Applied Economic Research, under a Project Sponsored by the National Food Security Mission, Ministry of Agriculture and Farmer's Welfare, GoI.

10. MoA\&FW, Annual Report 2014-15. Department of Agriculture, Cooperation and Farmers' Welfare, GoI.
11. Marshall, F., Ashmore, M. and Hinchcliffe, F., A hidden threat to food production: air pollution and agriculture in the developing world. Gate Keeper Series No. SA73-2, International Institute for Environment and Development under the Sustainable Agriculture and Rural Livelihoods Programme, London, UK.

12. Agrobiodiversity - Plant genetic resources, Deutsche Gesellschaft fur, International Zusammenarbeit (GIZ), GmbH prepared under the Sector Project Sustainable Agriculture (NAREN); www.giz.de/ sustainable-agriculture

13. Strategic scientific and technical issues related to the implementation of the Strategic Plan for Biodiversity 2011-2020. Biodiversity, Food System and Agriculture, 2015; UNEP/CBD/SBSTTA/ 19/INF/1.

14. FAO and Biodiversity for Food and Agriculture; http://www. cbdint/financial/idb2015/fao-foodagro.docx

15. Magdoff, F., Ecological agriculture: principles, practices and constraints. In Renewable Agriculture and Food Systems, Cambridge University Press, UK, 2007, vol. 22(2), pp. 109-117.

16. Tuck, S. L. et al., Land-use intensity and the effects of organic farming on biodiversity: a hierarchical meta-analysis. J. Appl. Ecol., 2014, 51, 746-755.

17. Sikkim Organic Mission, Government of Sikkim; www. sikkimorganicmission.gov.in (accessed on December 2018).

18. National Bureau of Plant Genetic Resources; http://www.nbpgr. ernet.in (accessed on December 2018).

19. Thomson Jacob, C., Parida, A. and Meenakumari, B., Mainstreamign biodiversity into agriculture sector for increasing India's food, nutritional and livelihood security. Centre for Biodiversity Policy and Law, National Biodiversity Authority, 2018, p. 34; ISBN: 978-81-932753-9-9.

20. Mohapatra, T., IAC Souvenir, 1st International Agrobiodiversity Congress, 6-9 November 2016, New Delhi, 2016, p. 142.

21. Vision 2050, ICAR-National Bureau of Animal Genetic Resources; http://nbagr.res.in

22. Totland, O., The state of knowledge about insect pollination in Norway - the importance of the complex interaction between plant and insects. Norwegian Biodiversity Information Centre, Norway, 2013.

23. Milfont, M., Rocha, E. E. M., Lima, A. O. N. and Freitas, B. M., Higher soybean production using honeybee and wild pollinators, a sustainable alternative to pesticides and auto pollination. Environ. Chem. Lett., 2013, 11, 335.

24. Potts, S. G., Imperatriz-Fonseca, V. L. and Ngo, H. T. (eds), The assessment report of the Intergovernmental Science-policy Platform on Biodiversity and Ecosystem Services on Pollinators, Pollination and Food Production. Secretariat of the IPBES, Bonn, Germany, 2016, p. 552.

25. Winfree, R. et al., Species turnover promotes the importance of bee diversity for crop pollination at regional scales. Science, 2018, 359, 791-793.

26. Gupta, A., Dadlani, M., Quek, P. and Mathur, P., Community Seed Banks - A Working Manual, Bioversity International, New Delhi, 2015.

27. Mainstreaming agrobiodiversity in sustainable food systems; www.bioversityinternational.org

ACKNOWLEDGEMENTS. We thank the Ministry of Environment Forest and Climate Change, Government of India, National Biodiversity Authority and the Norwegian Embassy, New Delhi for their support. We also acknowledge Dr B. Meenakumari and Mr T. Rabi Kumar (National Biodiversity Authority, Chennai) for their encouragement.

Received 27 April 2020; revised accepted 1 June 2020

doi: $10.18520 / \mathrm{cs} / \mathrm{v} 119 / \mathrm{i} 4 / 607-612$ 